\title{
Strategic Intelligence and Financial Performance in the Commercial Banks in Kenya
}

Blandina Walowe Kori, Stephen Makau Muathe and Samuel Mwangi Maina.

To Link this Article: http://dx.doi.org/10.6007/IJARBSS/v11-i3/8930 DOI:10.6007/IJARBSS/v11-i3/8930

Received: 01 January 2021, Revised: 30 January 2021, Accepted: 19 February 2021

Published Online: 06 March 2021

In-Text Citation: (Blandina et al., 2021)

To Cite this Article: Blandina, W. K., Stephen, M. A. M., \& Samuel, M. M. (2021). Strategic Intelligence and Financial Performance in the Commercial Banks in Kenya. International Journal of Academic Research in Business and Social Sciences, 11(3), 243-257.

Copyright: @ 2021 The Author(s)

Published by Human Resource Management Academic Research Society (www.hrmars.com) This article is published under the Creative Commons Attribution (CC BY 4.0) license. Anyone may reproduce, distribute, translate and create derivative works of this article (for both commercial and non-commercial purposes), subject to full attribution to the original publication and authors. The full terms of this license may be seen at: http://creativecommons.org/licences/by/4.0/legalcode

Vol. 11, No. 3, 2021, Pg. 243 - 257

Full Terms \& Conditions of access and use can be found at http://hrmars.com/index.php/pages/detail/publication-ethics 


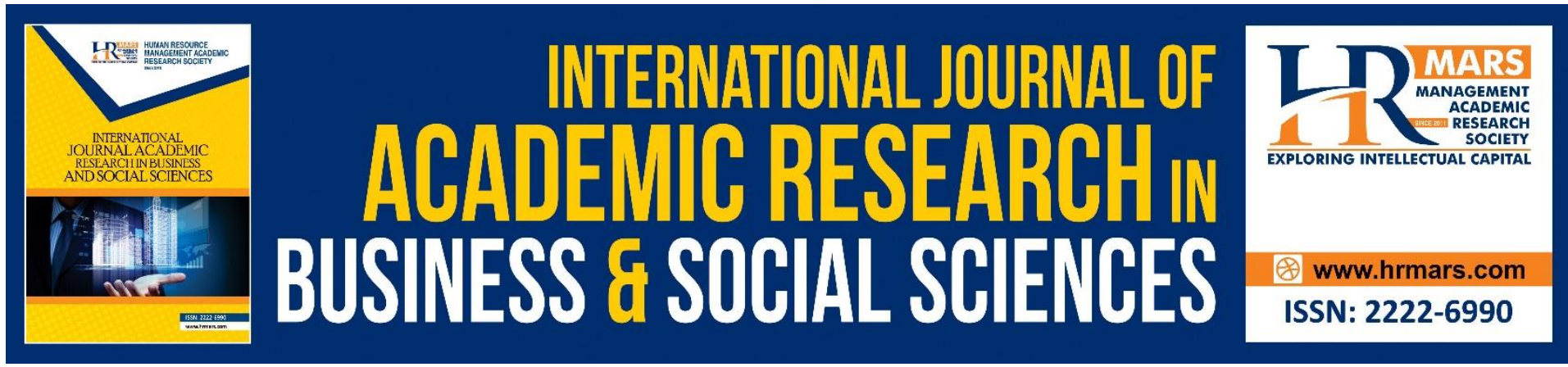

\title{
Strategic Intelligence and Financial Performance in the Commercial Banks in Kenya
}

\author{
Blandina Walowe Kori, Stephen Makau Muathe and Samuel \\ Mwangi Maina. \\ Kenyatta University, Nairobi, Kenya \\ Email: Koriblandina2016@gmail.com,muathesm@yahoo.com,maina.samuel@ku.ac.ke
}

\begin{abstract}
This study set to find out whether strategic intelligence has any effect on the financial performance on Kenyan commercial banks, establish whether it could be used to improve performance of the Kenyan banking sector and further support the economic growth of the country. The study conceptualized strategic intelligence as synergy of business intelligence, competitive intelligence and knowledge management. Data was obtained from the yearly records and publications of the central bank of Kenya, between the years 2016 - 2018. Further the researcher conducted simple linear multivariate analysis to confirm the outcome strategic intelligence has on the return on equity of the saving banks. Hypothesis testing was conducted at $P$-value $<0.5$. Findings indicated that strategic intelligence has a positive effect on the return on equity. The results showed that a unit increase of strategic intelligence led to a significant increase on the return on equity. Data collection was limited to the 40 registered Kenyan savings institutions. Further return on equity was used as financial measurement, for three consecutive years (2016 -2018), acquired from the yearly publications of the central bank of Kenya. The main objective was to identify the effect of strategic intelligence on the financial performance in Kenya. The study further revealed the benefits accrued in stability and sustainability of the banks, when strategic intelligence is employed. Moreover, this study exposed the setbacks that emerge in the absence of strategic intelligence in an individual commercial bank and the sector as a whole. The diversification of strategic intelligence of banks in Kenya should focus on growth of return on equity as the most attractive financial ratio, easy to interpret and the fast noticeable by investors, hence the major sources of revenue for the growth, stability and sustainability of the commercial banks in Kenya.
\end{abstract}

Keywords: Strategic Intelligence, Financial Performance, Return on Equity, Longitudinal study, Return on Assets, Commercial Banks

\section{Introduction}

Performance of an entity is a process of ensuring that the firm meets its set goals and objectives efficiently and effectively. additionally, performance involve the ability to maintain set standards within the business management system. Some scholars refer to it as a mixture of dissimilar outcomes which can be measured, gauged and valued in according to 
productivity, success, quality or quantity (Grittner, 2013). In banking industry performance is "efficiency" or the skillful procedure of producing income over a given period of time. Other researches relate bank performance to service, quality, innovation, technology or commitment of workers (Chai, Tan, \& Goh, 2016). Bikker (2010) identify the reliability of a financial institution in terms of solvency as another measure of performance of a bank. However, the scholar noted weaknesses in these measures in that investors may not be sure whether they will get their money back just in case of downturn.

In this study performance in banking is characterized with market value, which is normally reported through return on equity ratio (ROE). The researchers concur with other scholars that, ROE is the best measurement for performance due to increased equity capital which is supposed to lead to financial stability and predictably cost reduction due ensued economies of scale (Gudmundsson, Ngoka-Kisinguh \& Odongo, 2013). The emphasis is that, commendable banks' operations are described through their ability to maximizes their shareholders' value and the benefits accrued through the expected returns (Pennacchi \& Santos, 2018).

Research reveal that "good level of return on equity reflects a high level of profitability or more limited equity capital" (Bank, 2010). In this case directors align organisation objectives with the shareholders' interests to achieve higher returns. Thus, the standards are disseminated to all employees to ensures that the organisation members moves the same direction focusing on achieving the common goals by using different strategies. Moreover, analytical skills when deployed, help to make better results and solve complex problems. Analytical skills are strategic intelligence which have been found to be the engine in growing business organisations (Levine, Bernard \& Nagel, 2017).

Strategic intelligence helps the organisation to keep abreast with stiff competition in the market. Through strategic intelligence managers notice banks performance shifts as they emerge, hence act diligently to preempt competitors' tactics and maintain the targets (Awuah, 2011). Strategic intelligence is business intelligence or cognitive analysis, basic processes and activities such as financial management and operational planning, data collection and analysis, prediction of events, superb operational efficiency, risk management and higher rate of financial returns ( $\mathrm{Wu}$, Chen \& Olson, 2014). Strategic intelligence turns valuable decisions to an economic advantage, allowing the firms to foresee future trends of the banks and provide economic security (Courbe, 2016). It is through strategic intelligence that banks can make informed decision for growth and expansion. This is because strategic intelligence is foresight, vision, system thinking and motivation (Alhamadi, 2020).

In other words, strategic intelligence is the mind of the organisation hence aims to understand and foresee the future of the organisation and finds ways to maintain its competitiveness (Alomian, Alsawalhah \& Almarshad, 2019). Thus, it is a prerequisite for business success, it improves various information processes and increase value in the operation processes (Rajnoha et al., 2016). In this case firms engage strategic intelligence to make better decisions. Strategic intelligence plays a role of transformation, changing or upgrading systems, specifically the banking systems hence creating more agility operational efficiency (Harms, 2018). This an indication that intelligence leads to innovation, resulting to superior 
performance and high return on equity. Moreover, managers ability to grow an organisation or entrepreneurial behaviour is related to strategic intelligence (Ahmadi et al., 2020).

Strategic intelligence enables well-versed banks valuation to the economic value of a business, thus helping the managers to foresee future performance of the banks (Xu, 2007). Further, valuation intelligently assess the entity ability to generate and grow earnings, hence acting as motivator for more investments. As noted, some companies choose valuation indicators such as return on equity to disclose their performance status. Return on equity is a reflection of the investor's revenue and also the company's market worth (Pennacchi \& Santos, 2018). Moreover, it is evaluated against the cost of equity (COE), implying that the value created by the managers is cost effective hence attractive to shareholders (Norman, 2017).

Moreover, shareholders are assured of the safety of their money since bank deposits are insured by the government (Pennacchi \& Santos, 2018). In this case, shareholders select return on equity as base for analysing profitability and efficiency in a given firm. Another ratio that can be used in benchmarking for bank profitability is the return on assets (ROA). This measure compares a company's return on investment to other institutions, and it is a company's net income produced by total assets during a specified time (Remi, 2019). This measure also assesses efficiency of the directors and their ability to utilize the company's assets to maximise profits. However, return on assets does not show the real value added to the shareholder's capital. Moreover, return on assets has a tendence of encouraging the firms to continue using the available assets which may be obsolete and provide misleading information on the balance sheet (Lev, 2018).

The return on equity provides information concerning company's net income and its appropriateness for its size hence determining its probable worth in the future (De Mesnard, 2018). It is also preferred as a quick and easy metric to read and understand. Moreover, it is the most common accounting metric used to discern the compensation levels of bank managers (Pennacchi \& Santos, 2018). This form bases for intelligent decision making about the intended capital investments. Additionally, return on equity focuses on equity components and does not account for the price of stock, hence attractive to shareholders compared to return-on-investment capital (ROIC) (Henry, Robinson \& Van Greuning, 2012). Moreover, in comparison to return on investment capital, return on equity shows the profit earned by an individual company relative to the value of assets after subtracting debts, while return on investment capital does not, instead, it focuses on the profits generated by both equity and debt (Damodaran, 2007).

\section{Statement of the Problem}

According to Chironga, Cunha and DeGrandis (2018) Kenyan banking institution made recommendable profits which increased by $24.6 \%$ averagely, based on data from the year 2016. Accordingly, this is an indication that banks realized sound performance previously as compared the following years. However, in the financial period between $2017-2018$, some commercial banks performed dismally as shown on annual report of Central Bank of Kenya (2018). For example, while on the first tire the commercial banks had an average ROE of $26.43 \%$ in the year ended 2018 , the third tire recorded a $-2.79 \%$ in the same year.

Banks such as Equity and Kenya Commercial bank in the first tire, reported fair performance with a ROE of $40.20 \%$ and $32.10 \%$ respectively in the year 2018 but others such as DIB and Consolidated banks in third tier had a negative ROE of $-44.9 \%$ and $-38.00 \%$ respectively in that 
same year. This is an indication that there were some reasons that were affecting the performance of banks. According to Ekinci \& Poyraz (2019) the when one some banks records poor performance leads to decline of the economic value of the whole nation. Consequently, the drop in the return on equity in the banking sector necessitated the current research. According to Pellissier and Kruger (2011) strategic intelligence and all its dimensions facilitate banks superior performance since it facilitates solid decision-making.

\section{Reviewed Theoretical Literature}

The grounding theory of this study is the resources-based view (RBV). The resource-based view (RBV) in a managerial context seeks to comprehend reasons behind the growth and diversification of a firm. The theory was postulated by Penrose 1959, where the scholar relates internal managerial resources with growth and expansion of a firm (Kor \& Mahoney, 2005). This concept can be tested in economic development programmes or sectors such as performance in banking industry (Liu, Timothy \& Gao, 2010). Different authors discuss the resources-based theory (RBV), for example referring resources as basis of competitive advantage, which is achievable through calculated intelligence, where competitive intelligence is used as input for a winning strategy (Tahmasebifard, 2018). Other scholars argue that resources are capabilities found in business intelligence where technology, impact both process and overall organisation performance (Sidahmed, 2007).

Moreover, RBV is described as strategic intelligence of an organization with characteristics such as non-substitutable, scarce, ambiguous, socially complex and rear. Furthermore, a valuable resource is only true in the absence of heterogeneity, as it is with strategic intelligence (Adegbesan, 2009). Further, strategic intelligence in particular organisations stands unique, hence possessing the complexity and rareness characteristic of resourcebased view. Strategic intelligence skills are important resources in an organisation since they service intangible capabilities required to counter competitive threats, risks and opportunities (Levine, Bernard \& Nagel, 2017).

Thus, using Penrose's work, therefore, it is confirmed that there is close relationship between strategic intelligence and performance of firms such as the commercial banks. Resources based view is applicable in a very competitive unstable business environment such as the banking sector, accordingly, strategy and performance can advance resource-based view from theory to practice and return on assets (Liu, Timothy, \& Gao, 2010). The resource-based view theory has been challenged in that, due to high competition in the current volatile market, organisation are on the alert and keep on reshaping their business activities to catch up with the changing environment, hence dynamic capability theory complements the resource-based view (Gomes \& Romão, 2013).

Dynamic capabilities are aptitudes of the firm to bring together all its resources to manage the threats sounding them in the turbulent market environment (Teece, Pisano \& Shuen, 1997) as cited by Kori, Muathe and Maina (2020). Further, Teece et al., (1997) Argue that it is through dynamic capabilities that the firm grows and redesign its internal competence. Thus, these competences are differentiated from operational skills since they enable the organisation to generate, renew or modify their resources (Teece et al., 1997).

The organisation's fundamental competencies can be used to amend temporary viable business activities which may further enhance continuity, survival and attainment of competitive advantage (Faiz, 2014). However, this is possible when firm embrace adaptive capabilities which some scholars refer to it as a state of flexibility (Leavy, 2018). Adaptive 
activates are human skills, they enhance creativity and strengthens innovation capabilities among individual players in business milieus, hence leading to improved products, faster processes, organisational changes and market innovation capabilities (Karagouni, Protogerou \& Caloghirou, 2013; Piening \& Salge, 2015). Innovative capabilities are also referred to as subcapabilities, but also the incentives to superior performance of a firm (Kalyani, 2011).

There are other forms of capabilities know for faster growth of firms. Some of these capabilities are the networking capabilities which are on high-rate advancement due to current powerful technological capabilities. According to Muithya and Muathe (2020) network capabilities facilitate unity with the organisation and the stakeholders, which adds values to business growth and sustainability. Networking capabilities are an eye opener on available opportunities but also enhances detection of threats early in advance and tactically deal with them in good time (Lawson \& Samson, 2001).

Schrey"ogg and Kliesch-Eberl (2007) contend that capabilities are organisation's resources embedded in the routine activities for the growth and prosperity of the firm. Thus, through incorporating different systems and partnership in the companies, it becomes easy to overcome business challenges such strict regulatory requirements and stiff competition in banking industry, through learning and collaboration (Rajapathirana \& Hui, 2018). We therefore, argue that, businesses can only perform highly when they intelligently gather, process information and integrate their internal and external activities with advanced technologies, and this is strategic intelligence (Štefanikova \& Masarova, 2014).

The organisation need strategic intelligence for continuous transformation of their assets, constant environmental scanning and market evaluation to manage competitive forces surrounding them (Baaziz \& Quoniam, 2014). Moreover, organisations can consider integrating both tangible and intangible resources to curb stiff competition challenges (Teece, 2010). Finally, the managements are required to coordinate capabilities to produce desired surreptitious results in the firm management. Dynamic capabilities activate innovation, change management and improve commercial banks performance. Dynamic capabilities and knowledge management theories highlights reasons why firms differ. While dynamic capabilities focus more on identifying changing market environment, knowledge manage concentrates on alternative approaches of management and this is strategic intelligence (Easterby-Smith \& Prieto, 2008).

Knowledge management theory correspondingly complements the Resource Base View (Pitelis, 2007). The theory (knowledge management was developed by Nonaka in 1991 as an extension of resource-based view (McFarlane, 2011). This theory is considered basic and very important in the contemporary business milieu since knowledge does not depreciate, moreover, tacit knowledge can be temporarily immobile, hence can increase considerable revenue for a longer-term and attract more investors (Villasalero, 2017). It is business intelligence, competitive intelligence, and part of the synergy of strategic intelligence (Liebowitz, 2006).

In business settings management knowledge can either be explicit which is referred to as tacit knowledge or implicit referred to as intangible knowledge, whereby explicit knowledge can be codified and stored in document, while implicit knowledge is intelligencia and cannot be codified but can be shared among individuals in a firm (Omotayo, 2015). Thus, the storage and sharing of knowledge describes an intelligent behaviour of business organization AlSuwaidan and Zemirli (2015). It is an intellectual resource of a learning organisation hence leads to competitive advantage. Knowledge management is intelligence management. 
Knowledge is an enabler, enhance intellectual forecasting, identifies new trends, grows businesses, while managing current economic needs (Albescu, Pugna \& Paraschiv, 2008). Knowledge management enhances is real-time business reactions. It is innovative, activates creativity for more inventions, it is an intelligent process (Alavi \& Leidner, 2001; AlSuwaidan \& Zemirli, 2015). To perform outstandingly therefore, high standard of knowledge management in banking is inevitable (Madhani, 2010). Knowledge management is cognitive ability found on experience of employees and organisational routine (Mohajan, 2016). However, it is a complex practice since it may contain too many agents interacting with each other, hence becoming complicated to define Bennett \& Bennett (2014). It can also be termed as wisdom, expertise, knowledge, information and data management. Knowledge management is wisdom because it provides perfect solutions (Teo-Dixon \& Sayers, 2011). Knowledge management is the application of business management skills, decision making skills, learning and innovation, and communication skills (Mohanta, \& Thooyamani, 2010). Thus, knowledge management is strategic intelligence.

\section{Empirical Review}

The Kenyan banking sector which compasses commercial banks, foreign exchange bureaus, mortgage finances companies, the microfinance institutions, and operates directly under Central Bank (CBK) of Kenya as the main regulator (Central Bank of Kenya, 2018) as cited by Kori, Muathe, and Maina (2020). The banks classification is by ownership where some banks are local companies and others are foreign private owned. The main responsibility of the Central Bank of Kenya is to ensure security in all aspects through enforcing laws on cybercrimes, anti-money laundering and maintenance of the international standards concerning the banking business (Central Bank of Kenya, 2017).

Central Bank of Kenya together with other banking regulatory framework ensures consumer protection both in mortgage firms, deposit-taking microfinance companies, foreign and local commercial banks and in foreign bureaus (GoK Financial Sector Regulators Forum, 2018). The Kenya constitution Act no. 488 and the Central Bank Act. No. 491 thus, guides the operations of the banking sector in the country (Momanyi, 2018). Given that banking sector is one of the main drivers of the country's economy, supervision is mandatory for stability and sustainability (Central Bank of Kenya, 2017).

The report of Central Bank of Kenya (2018) indicate that the savings banks of Kenya were fourty (40) in number (not including the inoperational ones) either under statutory management or those in receivership. The classification of the commercial banks in Kenya follows three categories determined by the weighted composite index and tiers such as ( $1^{\text {st }}$ Tier = large banks, $2^{\text {nd }}$ Tier = medium-sized banks and $3^{\text {rd }}$ Tier = small banks) (Central Bank of Kenya, 2018). The tiers display the net assets or the book value of the stockholders; the customer deposits, capital and reserves, and profit before tax. Annual reports of 2016 indicated that banks recorded a higher profitability by $24.6 \%$ following the law of capping interest rate Chironga, Cunha and DeGrandis (2018). Further, the implementation of improved technology in the banking sector improved the services significantly (Chironga, Cunha \& De Grandis, 2018).

However, despite the positive indicators, commercial banks trends have not been stable. Data of 2016 show a decline on average of net interest margin from $8.96 \%$ to $8.4 \%$ in the year 2017 and $7.9 \%$ in the year 2018. Capital adequacy and assets quality also declined, which 
could be the major reason for the drop of interest margin (Central Bank of Kenya, 2018). According to Ekinci and Poyraz (2019) banks should remain afloat to maintain the economic status of the country. In case banks fail in strategy formulation, implementation and control, problems such as decline in profits occur (Fuertes et al., 2020). However, if banks implement strategies such cognitive skills, they can make informed decision and maintain the interest margin and superior performance of the sector (Pellissier \& Kruger, 2011).

Reviewed studies on banking sector in Kenya such as research by Musau, Muathe and Mwangi (2018) found that, implementation of financial inclusion in commercial banks positively impacted the financial stability. On the hand, Mutuku, Muathe and James (2019) revealed that e-commerce customization capability has a positive effect on Kenyan commercial banks' performance, while Kinyua, Muathe and Kilika (2015), established that knowledge conversion and knowledge transfer positively influenced performance in the banking sector. However, none of these studies carried out a longitudinal study on strategic intelligence and financial performance, moreover, the reviewed studies did not investigate return on equity as the main indicator in financial performance. Hence, due to drop on return on equity on the period under investigation, this study was necessary.

This study investigated the trend of commercial banks in Kenya in a three years period between 2016 - 2018. To verify the proposition therefore, the following hypothesis was tested:

H01: Strategic intelligence has no significant effect on the performance of commercial banks in Kenya.

\section{Research Methodology}

The target population of this study was 40 commercial banks. These were categorized on the bases of market share as large, medium and small size, found on the annual reports of $31^{\text {st }}$ December, 2018 (Central Bank of Kenya, 2018). As noted, the study employed secondary data acquired from the annual reports of the Central Bank of Kenya between 2016 - 2018. Data was analyzed through SSPS version 22 and presented in an ordinary linear regression model. In order to assess statistical significance, hypothesis testing was conducted at $P$-value $<0.5$. The financial measures were Return on Equity (ROE) and a simple regression model indicated below was used.

$$
\begin{aligned}
& \text { ROE }=\boldsymbol{\beta}_{\mathbf{0}}+\boldsymbol{\beta}_{1} \mathbf{S I}+\boldsymbol{\varepsilon} \\
& \text { Where } \\
& \text { ROE = Financial Performance } \\
& \boldsymbol{\beta}_{0}, \boldsymbol{\beta}_{1},=\text { Beta coefficients } \\
& \mathbf{S I}=\text { Strategic Intelligence } \\
& \boldsymbol{\varepsilon}=\text { Error Term }
\end{aligned}
$$

\section{Findings and Discussion}

The researcher used inferential statistics to predict the effect of strategic intelligence on the performance of commercial banks in Kenya. Figure: 1 indicate the trend for the performance of commercial banks in the period between 2016-2018. 


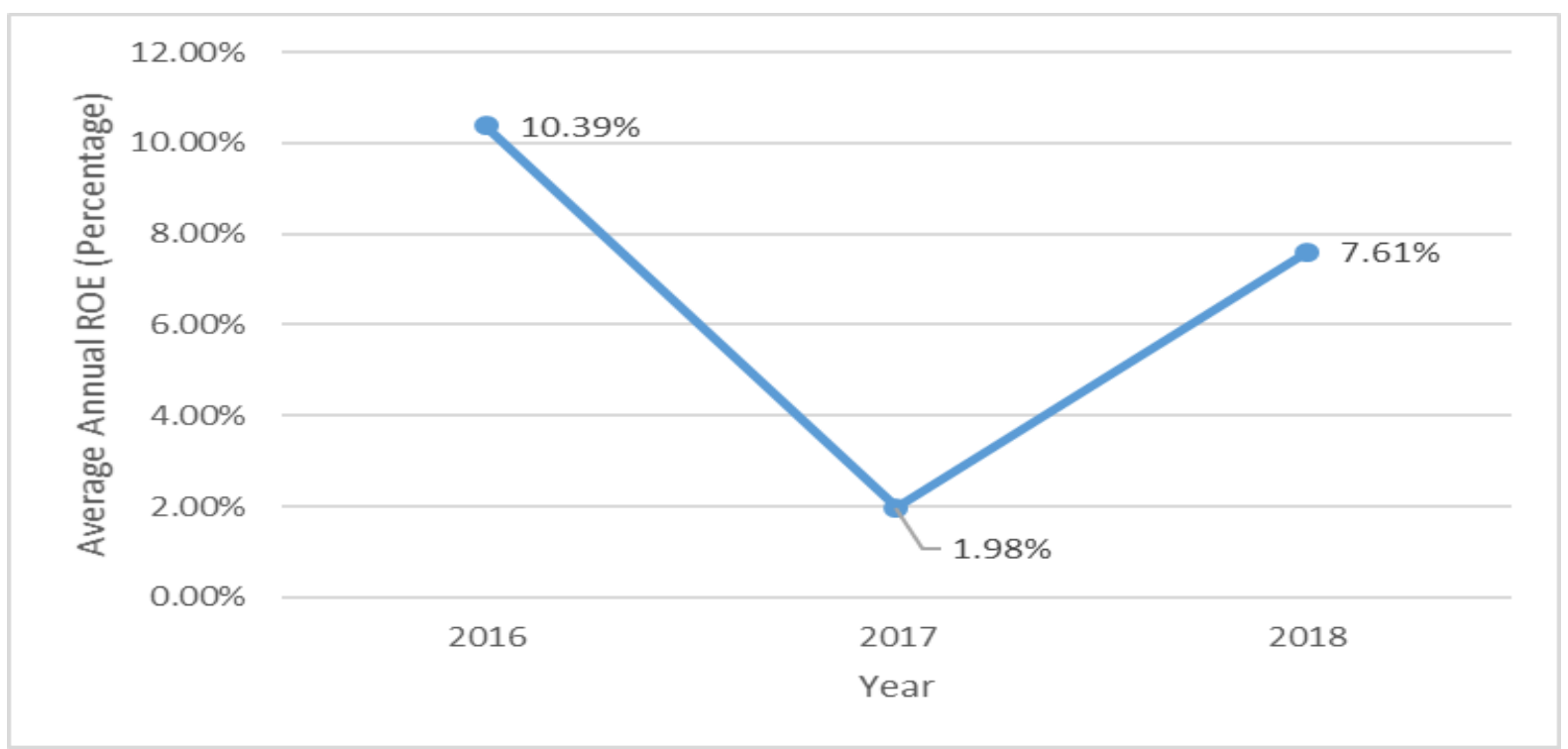

Figure.1 Trends in Financial Performance

Figure: 1 above shows the return for 3 years, with data obtained from the CBK annual records for three years as cited by Kori, Muathe and Maina (2020). The average return on equity for 2016 mean $=10.39,2017$ mean $=1.89$ and on 2018 mean $=10.39$ (Kori, Muathe \& Maina, 2020).

Further, the regression model was employed to find out the effect of strategic intelligence on performance of the banking industry in Kenya. The use of regression model would infer whether or not strategic intelligence caused or influenced performance of the banks. This would help the research to provide viable recommendation to bankers, whether or not they should practice strategic intelligence to forecast future returns on equity. The researcher tested the results using the model below:

$$
\mathrm{ROE}=\boldsymbol{\beta}_{0}+\boldsymbol{\beta}_{1} \mathrm{SI}+\varepsilon
$$

Table.1 Model Summary for Strategic Intelligence and Financial Performance

\begin{tabular}{lllll}
\hline Dependent Variable & $\mathbf{R}$ & $\mathbf{R}$ Square & Adjusted R Square & Std. Error of the Estimate \\
\hline ROE & 0.857 & 0.735 & 0.733 & 9.670111
\end{tabular}

The model linking strategic intelligence to return on equity in table 1 had an adjusted $R$ square value of 0.733 which implies that strategic intelligence had high explanatory power on return on equity, since $73.3 \%$ of the return on equity of commercial banks in Kenya can be explained by strategic intelligence. The model summary confirmed the goodness of fit, hence leading to the analysis of the residuals and the hypothesis testing.

In order to make conclusions on whether to reject or fail to reject the null hypothesis the ANOVA model was employed.

Table.2 ANOVA for Strategic Intelligence and Financial Performance

\begin{tabular}{lllllll}
\hline Dependent Variable & & Sum of Squares & Df & Mean Square & F & Sig. \\
\hline & Regression & 35796.17 & 1 & 35796.17 & 382.802 & .000 \\
& Residual & 12904.52 & 138 & 93.511 & & \\
ROE & Total & 48700.69 & 139 & & & \\
\hline
\end{tabular}

The results in table 2 indicate that the $F$ statistic value of 382.802 for the model linking strategic intelligence to return on equity was significant $(P$-value $=0.000)$. This implies that there are high chances that strategic intelligence is a major contributor towards financial 
performance of Kenyan banking sector. These results conform to the study carried out by (Kori, Muathe \& Maina, 2020).

To understand whether employing strategic intelligence in banking sector can lead to superior performance, the regression analysis was conduct.

Table.3 Regression Model Coefficients for Strategic Intelligence and Financial Performance

\begin{tabular}{|c|c|c|c|c|c|c|}
\hline \multirow[t]{2}{*}{$\begin{array}{l}\text { Dependent } \\
\text { Variable }\end{array}$} & & \multicolumn{2}{|c|}{$\begin{array}{l}\text { Unstandardized } \\
\text { Coefficients }\end{array}$} & \multirow{2}{*}{$\begin{array}{l}\text { Standardized } \\
\text { Coefficients } \\
\text { Beta }\end{array}$} & \multirow[t]{2}{*}{$\mathbf{t}$} & \multirow[t]{2}{*}{ Sig. } \\
\hline & & B & Std. Error & & & \\
\hline & (Consta & & & & 13.76 & 0.00 \\
\hline & $\mathrm{nt})$ & -27.896 & 2.026 & & 6 & 0 \\
\hline & & & & & 19.56 & 0.00 \\
\hline ROE & $\mathrm{SI}$ & 0.639 & 0.033 & 0.857 & 5 & 0 \\
\hline
\end{tabular}

The results in table 3 reveal that the strategic intelligence on return on equity of commercial banks in Kenya was positive and significant (Beta $=0.639, \mathrm{P}$-value $=0.000)$. These findings are consistent with that of Seitovirta (2011) which indicated that through strategic intelligence managers can easily collect data, analyse, distribute, plan and disseminate information, hence make sound decisions for the development of the industry and growth of economy as a whole. Further, the study concludes that strategic intelligence has a positive effect on the growth and sustainability of the banking sector. The results are in relation with the study of Kori, Muathe, Maina (2020). Accordingly, the researcher argues that if banking institutions in Kenya implement strategic intelligence, there will be increase in the return on equity, which will further attract more investors, thus growing the economy of the country.

\section{Conclusion}

This study was a longitudinal study whose main purpose was to investigate the effect of strategic intelligence on the financial performance. The results therefore indicate that, strategic intelligence positively affect financial performance of Kenyan commercial banks. More results indicated a down trend on the return on equity specially in the year 2017 . The study further established that a unit increase of strategic intelligence in banking would lead to, improved performance in form of increased return on equity. As noted, the improvement of performance in commercial banks would also lead to improved economic standing in the country. These results were consistence with the presupposed outcome by the researchers.

This study is important because it provides insights and contributes to practices, theories and policy formulation. The study may also be useful to Kenya commercial banks' managers, in that it can be used to enhance their strategic management processes. It may also be used to do proper environmental scanning and apply relevant strategies for better bank performance. The findings further, highlight key strategies on service delivery, customer retention and attraction of more investors. Moreover, findings bring forth more insights on innovation through utilization of return on equity. Further, the findings provide awareness on benchmarking and information on current and future business trends. In addition, the study shades light to the already present body of knowledge on different ways of investigating how resource-based theory, dynamic capability theory and knowledge management theory were applied on strategic intelligence and performance of commercial banks. 


\section{Policy Implications}

Based on the findings, this study recommends the following to the policy makers: that since the study established that strategic intelligence has great contribution to financial performance and specifically to return on equity, the commercial banks in Kenya should consider investing more on strategic intelligence. Moreover, the policy makers should keep close monitoring of their strategies, and more specifically they should monitor how intellectual resource is utilised in to increase financial performance in the sector. The diversification strategies should also focus on the growth of the return on equity as major sources of revenue. Further, more strategies should focus on how to retain current shareholders while encouraging potential investors to invest investment more.

\section{Scope study and future research}

This research sought to examine the effect of strategic intelligence on the of financial performance commercial banks in Kenya. Secondary data was acquired from the annual reports and publications of the Central Bank of Kenya, which provided the data on return on equity for years 2016-2018. This research contributes to the literature on strategic intelligence and banking. Moreover, this was a longitudinal research, which focused on return on equity (ROE) as measure of financial performance for three consecutive years (20162018). Other research can use a cross-sectional primary data or use different measurers for performance.

\section{References}

Adegbesan, J. A. (2009). On the Origins of Competitive Advantage: Strategic Factor Markets and Heterogeneous Resource Complementarity. Academy of management review, 34(3), 463-475. http://doi.org/10.5465/amr.2009.40632465

Ahmadi, M., Baei, F., Hosseini-Amiri, S. M., Moarefi, A., Suifan, T. S., \& Sweis, R. (2020). Proposing a model of manager's strategic intelligence, organization development, and entrepreneurial behavior in organizations. Journal of Management Development. 39(4), 559-579. https://doi.org/10.1108/JMD-11-2018-0317

Alavi, M., \&Leidner, D. E. (2001). Knowledge management and knowledge management systems: Conceptual foundations and research issues. MIS quarterly, 25(1), 107-136. http://doi.org/10.2307/3250961

Albescu, F., Pugna. Paraschi, D (2008). Business Intelligence \& Knowledge Management Technological Support for Strategic Management in the Knowledge Based Economy, Revista Informatica Economică, nr. 4(48), 5-12. http://doi.org/10.12691/ajis-2-2-1

Alhamadi, M. S. (2020). Impact of Strategic Intelligence on the sustainable competitive advantage of Industries Qatar. Global Journal of Management and Business Research. $20(2 \mathrm{~A}), 1-11$.

Alomian, N. R., Alsawalhah, A. A., \& Almarshad, M. N. (2019). The Impact of Strategic Intelligence on Achieving Competitive Advantage: Applied Study on the Pharmaceutical Companies Sector in Jordan. International Journal of Business and Social Science, 10(4), 66-74. http://doi.org/10.30845/ijbss. v10n4p8

AlSuwaidan, L., \& Zemirli, N. (2015). Toward a Knowledge-Based Model for Real-Time Business Intelligence. Journal in Science and Information Conference (SAI), 2015 (pp. 443-446). IEEE. http: :/doi.org/10.1109/SAI.2015.7237179 
Awuah, L. (2011). An evaluation of strategies for achieving competitive advantage in the banking industry. The case of Ghana commercial bank limited. Unpublished Executive MBA Research Project, Kwame Nkrumah University of Science and Technology.

Baaziz, A., \& Quoniam, L. (2014). Contribution to Reduce Risks Related to Strategic Decisions in New Uncertain Competitive Environments: The case of Algerian State-Owned Firms. Journal of Intelligence Studies in Business (JISIB), 4(1), 43-57.

Bank, E. C. (2010). Beyond roe-how to measure bank performance. Appendix to the report on EU banking structures.

Bennett, A., \& Bennett, D. (2014). Knowledge, theory and practice in knowledge management: Between associative patterning and context-rich action. Journal of Entrepreneurship, Management and Innovation, 10(4).7-55. http://doi.org/10.7341/20141011

Bikker, J. A. (2010). Measuring performance of banks: an assessment. Journal of applied Business and Economics, 11(4), 141-159.

Central Bank of Kenya (2017). 2017 Annual Report of Bank Supervision. Retrieved from banking_sector_annual_reports/873911276_2017\%20Annual\%20Report.pdf

Central Bank of Kenya (2018). Annual Report of Bank Supervision. Retrieved from banking_sector_annual_reports/1174296311_2018\%20Annual\%20Report.pdf

Chai, B. B. H., Tan, P. S., \& Goh, T. S. (2016). Banking services that influence the bank performance. Procedia-Social and Behavioral Sciences, 224, 401-407. http://doi.org/ 10.1016/j.sbspro.2016.05.405

Chironga, M., Cunha, L., \& De Grandis, H. (2018). Roaring to Life: Growth and Innovation in African Retail Banking. McKinsey \& Company.

Courbe, J. (2016). Financial services technology 2020 and beyond: embracing disruption. In $P W C$ (p. 48).

Damodaran, A. (2007). Return on capital (ROC), return on invested capital (ROIC) and return on equity (ROE): Measurement and implications. Return on Invested Capital (ROIC) and Return on Equity (ROE): Measurement and Implications (July 2007).

De Mesnard, L. (2018). EVA ( $\left.{ }^{\circledR}\right)$ vs. ROE as strategic corporate goals. A microeconomic approach (No. hal-01876449).

Easterby-Smith, M., \& Prieto, I. M. (2008). Dynamic capabilities and knowledge management: an integrative role for learning? British journal of management, 19(3), 235-249. http://doi.org/10.1111/j.1467-8551.2007.00543.x

Ekinci, R. \& Poyraz, G. (2019). The Effect Risk on Financial Performance of Deposit Banks in Turkey, $3^{\text {rd }}$ World Conference on Technology, Innovation and Entrepreneurship (WOCTINE). http://doi.org/10.1016/j.procs.2019.09.139

Faiz, M. A. (2014). Organization's Core Competencies; A Key for Successful \& Happy Organization. International Journal of Accounting and Business Management, 2(1), 6979.

Fuertes, G., Alfaro, M., Vargas, M., Gutierrez, S., Ternero, R., \& Sabattin, J. (2020). Conceptual Framework for the Strategic Management: A Literature Review-Descriptive. Journal of Engineering, 6253013, 1-21. http: ://doi.org/10.1155/2020/6253013

GoK Financial Sector Regulators Forum (2018). Financial sector stability (Report No. 9-5), Nairobi, Kenya Financial Sector Regulators Forum. 1371231931_Financial Stability Report 2017.pdf

Gomes, J., \& Romão, M. (2013). How Benefits Management Helps Balanced Scorecard to Deal with Business Dynamic Environments. Tourism \& Management Studies, 9(1), 129-138. 
Grittner, A. M. (2013). Results-based Financing: Evidence from performance-based financing in the health sector (No. 6/2013). Discussion Paper.

Gudmundsson, R., Ngoka-Kisinguh, K., \& Odongo, M. T. (2013). The role of capital requirements on bank competition and stability: The case of the Kenyan banking industry. Kenya Bankers Association-KBA Centre for Research on Financial Markets and Policy Working Paper Series.

Harms, T. (2018). Benefits and barriers of self-service business intelligence implementation in micro-enterprises: $\quad$ a case of $A B C$ Travel \& Consulting (Doctoral dissertation).

Henry, E., Robinson, T. R., \& Van Greuning, J. H. (2012). Financial analysis techniques. Financial reporting \& analysis, 327-385.

Kalyani, M. (2011). Innovative culture: an intervention strategy for sustainable growth in changing scenario. International Journal of Business Administration, 2(4), 84-92. http:// 10.5430/IJBA.V2N4P84

Karagouni, G., Protogerou, A., \& Caloghirou, Y. (2013). Autotelic capabilities and their impact on technological capabilities. Euro Med Journal of Business. 8(1), 48-63. http:// doi.org/10.1108/EMJB-05-2013-0020

Kinyua, G. M., Muathe, S. M. A., \& Kilika, J. M. (2015). Effect of knowledge conversion and knowledge application on performance of commercial banks in Kenya. International Journal of Education and Research, 3(10), 431-445.

Kor, Y. Y., \& Mahoney, J. T. (2005). How dynamics, management, and governance of resource deployments influence firm-level performance. Strategic Management Journal, 26(5), 489-496. http://doi.org/10.1002/smj.459

Kori, B. W., Muathe, S. M., \& Maina, S. M. (2020). Financial and Non-Financial Measures in Evaluating Performance: The Role of Strategic Intelligence in the Context of Commercial Banks in Kenya. International Business Research, 13(10), 130-142. https://doi.org/10.5539/ibr.v13n10p130

Lawson, B., \& Samson, D. (2001). Developing innovation capability in organisations: a dynamic capabilities approach. International journal of innovation management, 5(03), 377400. http://doi.org/10.1142/S1363919601000427

Leavy, B. (2018). Value innovation and how to successfully incubate 'blue ocean' initiatives. Strategy \& Leadership, 46(3), 10-20. https://doi.org/10.1108/SL-02-2018-0020

Lev, B. (2018). The deteriorating usefulness of financial report information and how to reverse it. Accounting and Business Research, 48(5), 465-493. https://doi.org/10.1080/00014788.2018.1470138

Levine, S. S., Bernard, M., \& Nagel, R. (2017). Strategic intelligence: The cognitive capability to anticipate competitor behavior. Strategic Management Journal, 38(12), 2390-2423. https://doi.org/10.1002/smj.2660

Liebowitz, J. (2006). Strategic intelligence: business intelligence, competitive intelligence, and knowledge management. CRC Press.

Liu, L., Timothy, V., \& Gao, Y. (2010). A review of approaches of resource-based empirical research in banking. The International Journal of Applied Economics and Finance, 4(4), 230-241.

Maccoby, M. (2015). Strategic intelligence: Conceptual tools for leading change. Oxford University Press, USA.

Maccoby, M., \& Scudder, T. (2011). Strategic Intelligence: A Conceptual System of Leadership for Change. Performance Improvement, 50(3), 32-40. https://doi.org/10.1002/pfi.20205 
Madhani, P. M. (2010). Resource based view (RBV) of competitive advantage: an overview. Resource Based View: Concepts and Practices, Pankaj Madhani, ed, 3-22.

McFarlane, D. A. (2011). Personal knowledge management (PKM): are we ready? Journal of Knowledge Management Practice, 12(3), 108-114.

Mohajan, H. (2016). Sharing of Tacit Knowledge in Organizations: A Review. American Journal of Computer Science and Engineering, 3 (2), 6-19.

Mohanta, G. C., \& Thooyamani, K. P. (2010). Perception of top-level knowledge workers on productivity improvement through tools and techniques. Journal of Management Research, 2(1), 1-18.

Momanyi, D. K. (2018). Influence of Financial Regulation in Kenya on Financial Inclusion: A Case Study of the Banking Industry in Kenya, August 2018, Working Paper Series Centre for Research on Financial Markets and Policy.

Muithya, V., \& Muathe, S. (2020) Dynamic Capabilities and Performance in the Context of Microfinance Institutions in Kenya: An Exploratory Study. International Journal of Business, Economics and Management Works.

Musau, S., Muathe, S., \& Mwangi, L. (2018). Financial inclusion, bank competitiveness and credit risk of commercial banks in Kenya. International Journal of Financial Research, 9(1), 203. http://doi.org/10.5430/ijfr.v9n1p203

Mutuku, M. K., Muathe, S., \& James, R. (2019). Mediating Effect of Competitive Advantage on the Relationship Between E-commerce Capability and Performance: Empirical Evidence from Commercial Banks in Kenya. European Journal of Business and Management, 11(17), 48-57. http://doi.org/10.7176/ejbm/11-17-06

Norman, D. (2017). Returns on Equity, Cost of Equity and the Implications for Banks. RBA Bulletin, March 51-58.

Omotayo, F. O. (2015). Knowledge Management as an important tool in Organisational: A Review of Literature. Library Philosophy and Practice. 1(2015), 1-23.

Pellissier, R. \& Kruger, J-P. (2011). 'Understanding the use of strategic intelligence as a strategic management tool in the long-term insurance industry in South Africa', SA Journal of Information. http:// doi.org/10.4102/sajim.v13i1.426

Pennacchi, G., \& Santos, J. A. (2018). Why do banks target ROE? FRB of New York Staff Report, (855).

Piening, E. P., \& Salge, T. O. (2015). Understanding the antecedents, contingencies, and performance implications of process innovation: A dynamic capabilities perspective. Journal of Product Innovation Management, 32(1), 80-97. http://doi.org/10.111/jpim.12225

Pitelis, C. (2007). Edith Penrose and a learning-based perspective on the MNE and OLI. Management International Review, 47(2), 207-219. https://doi.org/10.1007/s11575- 007-0012-6

Rajapathirana, R. J., \& Hui, Y. (2018). Relationship between innovation capability, innovation type, and firm performance. Journal of Innovation \& Knowledge, 3(1), 44- 55. http://doi.org/10.1016/j.jik.2017.06.002

Rajnoha, R., Štefko, R., Merkova, M., \& Dobrovič, J. (2016). Business intelligence as a key information and knowledge tool for strategic business performance management. Economics and management. 1 (XIX), 183-203. http://doi.org/ 10.15240/tul/001/2016-1-013

Remi, L. (2019). ROA, ROE, and What These Key Measures Mean for YOUR Bank. Weiss Rating. 
Schrey“ogg, G., Kliesch-Eberl, M. (2007). How dynamic can organizational capabilities be? Toward a dual process model of capability dynamization. Strategic Management Journal 28(9): 913-933. https://doi.org/10.1002/smj.613

Seitovirta, L. C. (2011). The role of strategic intelligence services in corporate decision making, That's not 'turbulence,' Chicken Little, it's really opportunity. Planning Review, 22(6), 7-9.

Sidahmed, M. (2007). Business intelligence impact assessment. AMCIS 2007 Proceedings, 205.

Štefanikova, L'., \& Masarova, G. (2014). The need of Complex Competitive Intelligence, Procedia-Social and Behavioral Sciences, 110, 669-677. https://doi.org/10.1016/j.sbspro.2013.12.911

Tahmasebifard, H. (2018). The role of competitive intelligence and its sub-types on achieving market performance. Cogent Business \& Management, 5(1), 1-16. https://doi.org/10.1080/23311975.2018.1540073

Teece, D. J. (2010). Business models, business strategy and innovation. Long range planning, 43(2-3), 172-194. https://doi.org/10.1016/j.Irp.2009.07.003

Teece, D. J., Pisano, G., \& Shuen, A. (1997). Dynamic capabilities and strategic management. Strategic management journal, 18(7), 509-533. https://doi.org/10.1002/(SICI)1097-0266(199708)18:7<509::AID-SMJ882>3.0.CO;2-Z

Teo-Dixon, G., \& Sayers, J. (2011). Wisdom as knowledge management's perfect solution: a word of caution. Philosophy of Management, 10(1), 61-77.

Villasalero, M. (2017). A resource-based analysis of realized knowledge relatedness in diversified firms. Journal of Business Research, 71, 114-124. https://doi.org/10.1016/j.jbusres.2016.10.011

Wu, D. D., Chen, S. H., \& Olson, D. L. (2014). Business intelligence in risk management: Some recent progresses. Information Sciences, 256, 1-7. https://doi.org/10.1016/j.ins.2013.10.008

$\mathrm{Xu}, \mathrm{M}$. (Ed.). (2007). Managing Strategic Intelligence: Techniques and Technologies: Techniques and Technologies. IGI Global. 